\section{To: (Receiving organization)} Distribution
3. From: (Originating organization)

D. E. P1 ace, SESC, H5-27 376-0176

6. Design Authority/ Design Agent/Cog. Engr.:
5. Proj./Prog./Dept./Div.:

Tank 241-TX-117 For Release gm8/25/97

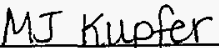

8. Originator Remarks:

11A. Design Baseline Document?

[] Yes [x] No

4. Related EDT No.:

NA

7. Purchase Order No.:

NA

9. Equip./Component No.: NA

10. System/Bldg./Facility: NA

12. Major Assm. Dwg. No.:

NA

13. Permit/Permit Application No.:

NA

14. Required Response Date:

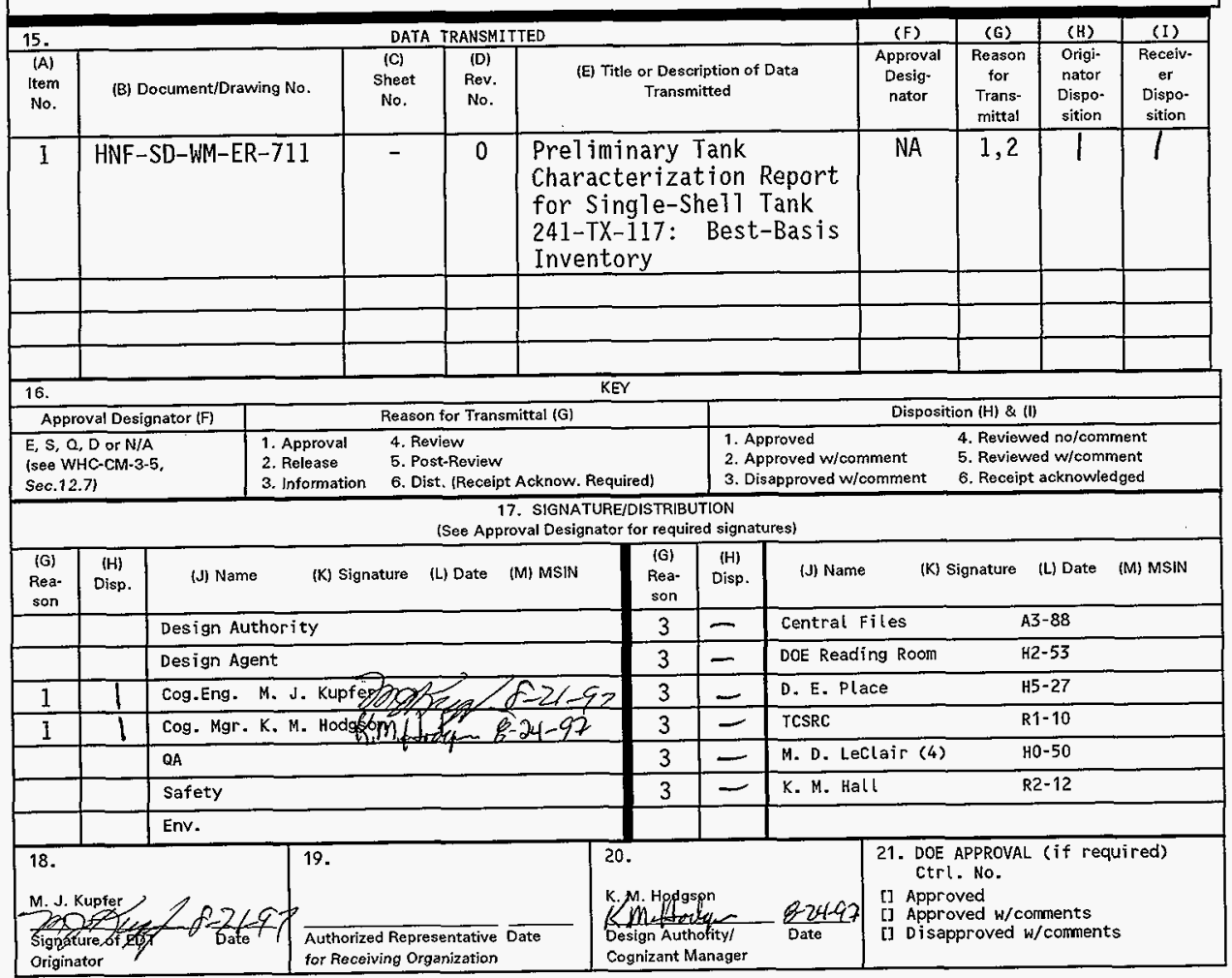

BD-7400-172-2 (05/96) GEF097 


\title{
Preliminary Tank Characterization Report for Single-Shell Tank 241-TX-117: Best-Basis Inventory
}

\author{
D. E. Place \\ SGN Eurisys Services Corporation, Richland, WA 99352 \\ U.S. Department of Energy Contract DE-AC06-96RL13200
}

$\begin{array}{lll}\text { EDT/ECN: } & 622652 & \text { UC: } 712 \\ \text { Org Code: } & 746 / 0 & \text { Charge Code: } \\ \text { B\&R Code: } & \text { EW3 } 120074 & \text { Total Pages: } 36 \text { g5 } 8 / 25 / 97\end{array}$

Key Words: TCR, best-basis inventory

Abstract: An effort is underway to provide waste inventory estimates that will serve as standard characterization source terms for the various waste management activities. As part of this effort, an evaluation of available information for single-shell tank 241-TX-117 was performed, and a best-basis inventory was established. This work follows the methodology that was established by the standard inventory task.

TRADEMARK DISCLAIMER. Reference herein to any specific commercial product, process, or service by trade name, trademark, manufacturer,. or otherwise, does not necessarily constitute or imply its endorsement, recommendation, or favoring by the United states Government or any agency thereof or its contractors or subcontractors.

Printed in the United States of America. To obtain copies of this document, contact: Document Control Services, P.D. Box 950, Mailstop H6-08, Richland WA 99352, Phone (509) 372-2420; Fax (509) 376-4989.
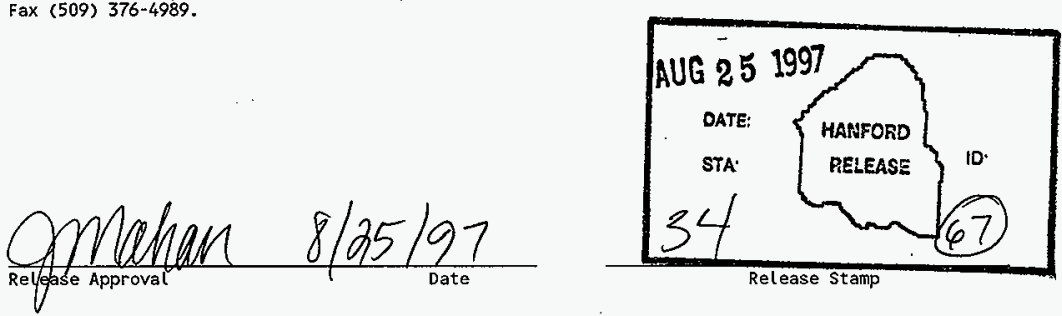
HNF-SD-WM-ER-711

Revision 0

\section{PRELIMINARY TANK CHARACTERIZATION REPORT FOR SINGLE-SHELL TANK 241-TX-117: BEST-BASIS INVENTORY}

June 1997

D. E. Place

SGN Eurisys Services Corporation

Richland, Washington

Prepared for

U.S. Department of Energy

Richland, Washington 
HNF-SD-WM-ER-711

Revision 0

This page intentionally left blank. 
HNF-SD-WM-ER-711.

Revision 0

\section{PRELIMINARY TANK CHARACTERIZATION REPORT \\ FOR SINGLE-SHELL TANK 241-TX-117: \\ BEST-BASIS INVENTORY}

This document is a preliminary Tank Characterization Report (TCR). It only contains the current best-basis inventory (Appendix D) for single-shell tank 24l-TX-117. No TCRs have been previously issued for this tank, and current core sample analyses are not available. The best-basis inventory, therefore, is based on an engineering assessment of waste type, process flowsheet data, early sample data, and other available information.

The Standard Inventories of Chemicals and Radionuclides in Hanford Site Tank Wastes (Kupfer et al. 1997) describes standard methodology used to derive the tank-by-tank best-basis inventories. This preliminary TCR will be updated using this same methodology when additional data on tank contents become available.

\section{REFERENCE}

Kupfer, M. J., A. L. Boldt, B. A. Higley, K. M. Hodgson, L. W. Shelton, B. C. Simpson, and R. A. Watrous (LMHC), S. L. Lambert, and D. E. Place (SESC), R. M. Orme (NHC), G. L. Borsheim (Borsheim Associates), N. G. Colton (PNNL), M. D. LeClair (SAIC), R. T. Winward (Meier Associates), and W. W. Schulz (W'2 S Corporation), 1997, Standard Inventories of Chemicals and Radionuclides in Hanford Site Tank Wastes, HNF-SD-WM-TI-740, Rev. 0, Lockheed Martin Hanford Corporation, Richland, Washington. 


\section{HNF-SD-WM-ER-711}

Revision 0

This page intentionally left blank. 
HNF-SD-WM-ER-711

Revision 0

\section{APPENDIX D}

\section{EVALUATION TO ESTABLISH BEST-BASIS INVENTORY FOR SINGLE-SHELL TANK 241-TX-117}


HNF-SD-WM-ER-711

Revision 0

This page intentionally left blank. 
HNF-SD-WM-ER-711

Revision 0

APPENDIX D

\section{EVALUATION TO ESTABLISH BEST-BASIS INVENTORY FOR SINGLE-SHELL TANK 241-TX-117}

An effort is underway to provide waste inventory estimates that will serve as standard characterization source terms for the various waste management activities (Hodgson and LeClair 1996). As part of this effort, an evaluation of available information for single-shell tank 241-TX-117 was performed and a best-basis inventory was established. This work, detailed in the following sections, follows the methodology that was established by the standard inventory task.

\section{D1.0 CHEMICAL INFORMATION SOURCES}

Available chemical and radiological inventory estimates for tank 241-TX-117 consist only of the inventory estimate generated by the Hanford Defined Waste (HDW) model (Agnew et al. 1997a). No Tank Characterization Report (TCR) has been previously issued for this tank, and core sample analyses are not available. The best-basis inventory, therefore, is based on the waste types contained in tank 241-TX-117 and composition data from other Hanford Site tanks containing similar waste types.

\section{D2.0 COMPARISON OF COMPONENT INVENTORY VALUES}

The tank 241-TX-117 chemical and radionuclide inventory predicted by the HDW model (Agnew et al. 1997a) is provided in Table D2-1. The chemical species are reported without charge designation per the best-basis inventory convention. The HDW model inventory is based on $1,904 \mathrm{~kL}$ ( $503 \mathrm{kgal}$ ) of salt cake produced by the $242-\mathrm{T}$ Evaporator and $110 \mathrm{~kL}(29 \mathrm{kgal})$ of diatomaceous earth. 
HNF-SD-WM-ER-711

Revision 0

Table D2-1. Hanford Defined Waste Model Prediction of

Tank 241-TX-117 Inventory. (2 sheets)

\begin{tabular}{|c|c|}
\hline Analyte & $\begin{array}{l}\text { Hanford Defined Waste model } \\
\text { inventory }{ }^{a}(\mathrm{~kg})\end{array}$ \\
\hline $\mathrm{Al}$ & 37,400 \\
\hline $\mathrm{Bi}$ & 2,840 \\
\hline $\mathrm{Ca}$ & 4,500 \\
\hline $\mathrm{Cl}$ & 8,960 \\
\hline $\mathrm{CO}_{3}$ & 30,900 \\
\hline $\mathrm{Cr}$ & 5,280 \\
\hline$F$ & 3,440 \\
\hline $\mathrm{Fe}$ & 6,310 \\
\hline $\mathrm{Hg}$ & 3.75 \\
\hline $\mathrm{K}$ & 2,520 \\
\hline $\mathrm{La}$ & $1.39 \mathrm{E}-04$ \\
\hline $\mathrm{Mn}$ & 139 \\
\hline $\mathrm{Na}$ & 534,000 \\
\hline $\mathrm{Ni}$ & 908 \\
\hline $\mathrm{NO}_{2}$ & 96,200 \\
\hline $\mathrm{NO}_{3}$ & 725,000 \\
\hline $\mathrm{OH}$ & 139,000 \\
\hline $\mathrm{Pb}$ & 305 \\
\hline $\mathrm{PO}_{4}$ & 103,000 \\
\hline $\mathrm{Si}$ & 19,700 \\
\hline $\mathrm{SO}_{4}$ & 31,300 \\
\hline $\mathrm{Sr}$ & 0 \\
\hline TOC & 4,060 \\
\hline $\mathrm{U}$ & 15,200 \\
\hline $\mathrm{Zr}$ & 69.7 \\
\hline
\end{tabular}


HNF-SD-WM-ER-711

Revision 0

Table D2-1. Hanford Defined Waste Model Prediction of Tank 241-TX-117 Inventory. (2 sheets)

\begin{tabular}{|c|c|}
\hline Analyte & $\begin{array}{c}\text { Hanford Defined Waste model } \\
\text { inventory }(\mathrm{kg})\end{array}$ \\
\hline Radionuclide $^{\mathrm{b}}(\mathrm{Ci})$ & 315,000 \\
\hline${ }^{137} \mathrm{Cs}$ & 86,000 \\
\hline${ }^{90} \mathrm{Sr}$ &
\end{tabular}

"Agnew et al. (1997a)

${ }^{b}$ Revision 4 of the HDW model (Agnew et al. 1997a) contains estimates for 46 radionuclides. Only the two most prevalent, ${ }^{90} \mathrm{Sr}$ and ${ }^{137} \mathrm{Cs}$, are listed in this table. The HDW model radionuclide predictions are baselined to January 1, 1994.

\section{D3.0 COMPONENT INVENTORY EVALUATION}

\section{D3.1 CONTRIBUTING WASTE TYPES}

The HDW model (Agnew et al. 1997a), the Sort on Radioactive Waste Type (SORWT) model (Hill et al. 1995) and the waste tank summary report (Hanlon 1997) are not entirely consistent as to their reporting of the waste types present in tank 241-TX-117 and the total tank waste volume. The HDW model includes a diatomaceous earth layer that is not reported by the other two documents. The HDW model tank inventory is based on total waste volume of $2,014 \mathrm{~kL}(532 \mathrm{kgal})$, which is $356 \mathrm{~kL}$ (94 kgal) less than that reported in the other documents.

The HDW model (Agnew et al. 1997a) predicts that the tank contains $746 \mathrm{~kL}$ (197 kgal) of T1 SltCk, 1,158 kL (306 kgal) of SMMT2 salt cake predicted from the Supernatant Mixing Model (SMM), and $110 \mathrm{~kL}(29 \mathrm{kgal})$ of diatomaceous earth. The HDW model (Agnew et al. 1997a) refers to 242-T Evaporator salt cakes formed during the time period of 1951-1955 as T1 SltCk. The HDW model refers to 242-T Evaporator salt cakes formed during the period of 1965-1976 as T2 SltCk on a.global basis, or SMMT2 when calculated for an individual tank by the SMM.

The Sort on Radioactive Waste Type (SORWT) model (Hill et al. 1995) lists EB (evaporator bottoms) and $1 \mathrm{C}$ (first decontamination cycle $\mathrm{BiPO}_{4}$ waste) as the primary and secondary waste types, respectively, but credits the entire tank 241-TX-117 volume $(2,369 \mathrm{~kL}$ [626 kgal]) to salt cake with $30 \mathrm{~kL}$ (8 kgal) of interstitial liquid. Hanlon (1997) also indicates that the entire tank inventory is salt cake. 
HNF-SD-WM-ER-711

Revision 0

\section{D3.2 EVALUATION OF TECHNICAL FLOWSHEET INFORMATION}

Waste transaction records (Agnew et al. 1997b) show that tank 241-TX-117 was initially filled with $1 \mathrm{C}$ waste supernatant transferred from tanks $241-\mathrm{T}-106$ and 241-T-105 in the first and second quarters of 1951. Tank 241-T-105 contained a significant volume of well-settled $1 \mathrm{C}$ and $2 \mathrm{C}$ sludge at the time. Some solid material may have been included in the transfer, depending on the transfer method used. The $1 \mathrm{C}$ supernatant was transferred to tank 241-TX-118 in the third quarter of 1951, leaving the tank essentially empty.

The waste transaction records (Agnew et al. 1997b) show that tank 241-TX-117 began receiving 242-T Evaporator bottoms in the fourth quarter of 1951 . A total of $21,631 \mathrm{~kL}$ $(5,715 \mathrm{kgal})$ of concentrated salt solutions were routed through tank $241-\mathrm{TX}-117$ between the fourth quarter of 1951 and third quarter of 1955 . The evaporator bottoms received in tank 241-TX-117 were often transferred to other tanks, including 241-T-108, 241-T-109, 241-TX-112, 241-TX-114, 241-TY-101, and 241-TY-102. The supernatants from salt cakes formed in tank 241-TX-117 were recycled to the evaporator feed tank (241-TX-118). The deposition of a large salt cake layer in tank 241-TX-117 would normally be expected.

Tank 241-TX-117 again received concentrated evaporator bottoms from the 242-T Evaporator and recycled supernatants to the evaporator beginning in the first quarter of 1966 and continuing intermittently until the fourth quarter of 1971 (Agnew et al. 1997b). Anderson (1990) indicates that the supernatant had been removed from the tank by the first quarter of 1971, and that an initial removal of interstitial liquid occurred in the second quarter of 1971. Regardless of the exact ending date, salt would have precipitated as the concentrated salt solutions cooled, and a large $\mathrm{T} 2$ salt cake layer would have been deposited on top of previously existing salt cake.

Three truck loads of diatomaceous earth (approximately $40.8 \mathrm{MT}$ ) were added to the tank in November 1970 (Buckingham and Metz 1974). The diatomaceous earth, consisting primarily of silicon dioxide, was added to demonstrate liquid immobilization using a absorbent solid.

Agnew et al. (1997b) indicates that salt well pumping of the interstitial liquid occurred in fourth quarter of 1981, in the first and second quarters of 1982, and in the fourth quarter of 1983. Anderson (1990) does not report events beyond 1980.

\section{D3.3 DETERMINATION OF WASTE VOLUMES}

There is a possibility that some $1 \mathrm{C}$ and $2 \mathrm{C}$ sludges were transferred to tank 241-TX-117 with the 241-T-105 1C waste supernatant transfers in 1951. The sludges in tank 241-T-105 would have been well settled at the time, and no significant solids would have been transferred if the supernatant was decanted. Since there were no solids level measurements in tank 241-TX-117 to indicate a sludge layer, it will be assumed that the volume of solids transferred, if any, is negligible. 
The HDW model estimates the T1 salt cake volume based on a solids volume measurement made in the first quarter of 1965 (746 kL [197 kgal] of T1 salt cake). A total of $21,631 \mathrm{~kL}(5,715 \mathrm{kgal})$ of T1 salt cake supernatant was transferred to tank $241-\mathrm{TX}-117$, which is considered sufficient to have produced the $746 \mathrm{~kL}(197 \mathrm{kgal})$ of T1 SltCk.

Waste transaction records (Agnew et al. 1997b) show that tank 241-TX-117 received $33,164 \mathrm{~kL}(8,762 \mathrm{kgal})$ of concentrated 242-T Evaporator waste between 1966 and 1971. One transfer of evaporator bottoms was made to tank 241-TX-108 in the third quarter of $1966(1,779 \mathrm{~kL}$ [470 kgal]). With the exception of the one transfer, the evaporator bottoms were cooled in tank 241-TX-117, salt precipitated, and the salt cake supernatants were recycled to the evaporator feed tank (241-TX-118). This volume is considered sufficient to account for T2 salt cake accumulated in tank $241-\mathrm{TX}-117$.

The HDW model estimates that the T2 salt cake volume is $1,158 \mathrm{~kL}$ ( $306 \mathrm{kgal})$. This volume of $\mathrm{T} 2$ salt cake is calculated by subtracting the $\mathrm{T} 1$ salt cake volume $(746 \mathrm{~kL}$ [197 kgal]), the diatomaceous earth volume $(110 \mathrm{~kL}$ [29 kgal]), and the estimated interstitial liquid removed $(356 \mathrm{~kL}$ [94 kgal]) from the waste volume indicated by a December 31,1971 solids volume measurement $(2,369 \mathrm{~kL}$ [626 kgal]).

Later solids level measurements in tank 241-TX-117 are unreliable because the manual tape is located above a 2 -foot diameter hole in the sait cake created by the removal of a pump (Swaney 1993). The $356 \mathrm{~kL}$ (94 kgal) of interstitial liquid removed reported by Agnew et al. (1997b) is based on low-quality data, and does not agree with the $206 \mathrm{~kL}$ (54.3 kgal) volume reported by Hanlon (1997). The HDW model assumption that removal of interstitial liquid causes an equal decrease in the salt cake volume is unsubstantiated. Anderson 1990 reports that removal of $.102 \mathrm{~kL}(27 \mathrm{kgal})$ of interstitial liquid from tank 241-TX-117 in the second quarter of 1971 did not cause a corresponding drop in the level of the solids. The total waste volume of $2,369 \mathrm{~kL}$ ( $626 \mathrm{kgal})$ reported by Hanlon (1997) will be used for estimating the tank inventory.

The HDW model assumes a density of $0.39 \mathrm{~g} / \mathrm{mL}$ for diatomaceous earth. This is roughly the equivalent of the $24 \mathrm{lbs} / \mathrm{cubic}$ foot as-delivered packed density reported by the vendor (Buckingham and Metz 1974). The HDW model makes no provision for absorption of liquid waste by the diatomaceous earth. However, this appears to be an appropriate assumption for the tank 241-TX-117 inventory determination.

An April 11, 1983 composite photograph of the tank 241-TX-117 interior (Brevick et al. 1997) shows the mounding of bright white solids on the waste surface. The diatomaceous earth does not appear to be dispersed into the salt cake. The composite photograph for the interior tank 241-TX-116, which also received diatomaceous earth, does not show a separate layer of diatomaceous earth on the waste surface, and the tank 241-TX-116 analytical results which showed high silicon concentrations extending $203 \mathrm{~cm}$ (80 in.) down into the salt cake (Horton 1977). As the result of these observations, it will be assumed that the diatomaceous earth has the density corresponding to the as-delivered packed density and occupies the 
$110 \mathrm{~kL}$ (29 kgal) layer predicted by the HDW model. It will also be assumed that the diatomaceous earth layer in tank 241-TX-117 includes a negligible quantity of absorbed waste components:

\section{D3.4 COMPOSITION OF TANK 241-TX-117 WASTE}

\section{D3.4.1 Composition of T1 Salt Cake}

Operation of the 242-T Evaporator between 1951 and 1955 resulted in $2,903 \mathrm{~kL}$ (767 kgal) of salt cake, which is contained in 10 underground storage tanks in the T, TX, and TY Tank Farms (Agnew et al. 1997a). The evaporator feeds during this time period consisted largely of $1 \mathrm{C}$ and tributyl phosphate (TBP) waste supernatants. The HDW model refers to this salt cake as T1 SltCk on a global basis. The HDW model uses this average T1 SltCk composition to calculate the $\mathrm{T} 1$ salt cake inventories for individual tanks rather than its SMM because of the lack of detailed evaporator feed composition data. The salt cake produced by the 242-T Evaporator from 1951 through 1955 will be referred to as T1 salt cake hereafter in this report. Seventy-nine percent of the T1 salt cake is contained in the TX Tank Farm. With the exception of tank 241-T-109, all tanks containing T1 salt cake also contain other waste types. Five of the tanks containing T1 salt cake have been core or auger sampled (tanks 241-T-108, 241-T-109, 241-TX-116, 241-TY-101, and 241-TY-102).

The auger samples for tanks 241-T-108 and 241-T-109 are recent (1995) and laboratory analyses should meet all Hanford Federal Facility Agreement and Consent Order (Tri-Party Agreement) (Ecology et al. 1994) requirements. Tank 241-T-108 is expected to contain $1 \mathrm{C} / \mathrm{CW}$ sludge as well as $\mathrm{T} 1$ salt cake (Agnew et al. 1997a), however the analytical results indicate that the tank 241-T-108 sample retrieved was primarily salt cake as evidenced by the high sodium concentration $(223,000 \mu \mathrm{g} / \mathrm{g})$ reported for the composite (Baldwin 1996). Tank 241-T-109 contains only $\mathrm{T} 1$ salt cake generated from the 242-T Evaporator concentration of TBP and $1 \mathrm{C} / \mathrm{CW}$ supernatants. The composition of the tank 241-T-109 salt cake is somewhat unusual in that it is primarily sodium phosphate rather than sodium nitrate. The composition reported by the TCRs for tank 241-T-108 (Baldwin et al. 1996) and for tank 241-T-109 (Brown et al. 1996) are included in Table D3-1.

T1 salt cake was deposited in tank 241-TX-116 between 1951 and 1955. The tank 241-TX-116 core sample was taken with the initial prototype of a rotary core sampler in 1976 to 1977 (Allen 1977). Sample recoveries were relatively poor and no material was recovered from several segments. Additionally, analytical methods and quality assurance requirements differed significantly from current practices. The analytical data are provided in a letter report (Horton 1977). Core segments 6, 7, 9, and 10 are expected to be T1 salt cake based on the HDW model layer volumes, and this is confirmed by differences in the core sample results as compared to segments 1 through 4 (T2 salt cake). No material was recovered in segments 5 and 8 . The analytical results were corrected to a silicon-free basis 
since diatomaceous earth (92 percent $\mathrm{SiO}_{2}$ ) was added to tank 241-TX-116 in November of 1970 (Buckingham and Metz 1974). The analytical results are included in Table D3-1.

Tanks 241-TY-101 and 241-TY-102 were core sampled in 1985. As with the tank 241-TX-116 core sample, the analytical methods and quality assurance differed from current practices. Tank 241-TY-101 contains ferrocyanide scavenging wastes as well as salt cake. The relatively low sodium concentration reported for the composite $(121,000 \mu \mathrm{g} / \mathrm{g}$, Weiss and Mauss 1987a) indicates that the sample was primarily sludge and that the data are not appropriate examples of $\mathrm{T} 1$ salt cake. Tank $241-\mathrm{TY}-102$ contains both $\mathrm{T} 1$ and $\mathrm{T} 2$ salt cakes (about 45 percent $\mathrm{T} 1$ salt cake). Since only composite analyses were performed, the results can not be used as an example of T1 salt cake.

However, it should be noted that the phosphate concentration for tank 241-TY-102 is relatively low $(29,000 \mu \mathrm{g} / \mathrm{g}$, Weiss and Mauss $1987 \mathrm{~b})$, indicating that the phosphate concentration of the T1 salt cake added to tank 241-TY-102 could not have been comparable to concentrations measured for tanks $241-\mathrm{T}-108$ and 241-T-109 $(125,000$ and $246,000 \mu \mathrm{g} / \mathrm{g}$, respectively, Table D3-1). Phosphate concentrations exceeding 100,000 $\mu \mathrm{g} / \mathrm{g}$ are not necessarily typical of T1 salt cakes based on the analytical results for tanks 241-TY-102 and 241-TX-116. The reason for this wide variation in phosphate concentration is not known, but supernatants recycled from salt receiving tanks to the 242-T Evaporator might have been depleted in phosphate, and consequently the salt cakes formed from recycled supernatants would have a lower phosphate concentration.

The analytical data for tanks 241-T-108, 241-T-109, and 241-TX-116 are tabulated in Table D3-1. The relative standard deviation of the mean for all components except sodium and zirconium are extremely high, indicating that the composition of the waste type is extremely variable. Any model which assumes that $\mathrm{T} 1$ salt cake has a relatively consistent composition, including the prediction in Table D3-1 or the HDW model (Agnew et al. 1997a), will have very limited usefulness in predicting the inventory of a tank containing T1 salt cake. The composition predicted by the HDW model for the global composition of T1 salt cake is included in Table D3-1 for comparison. With the exception of sodium and nitrate, the predicted $\mathrm{T} 1$ salt cake composition differs significantly from the HDW model T1 SltCk concentrations for most chemical analytes. The predicted T1 salt cake concentrations used to calculate the tank 241-TX-117 inventory for this evaluation will be based on the average of the concentrations in tanks 241-T-108, 241-T-109, and 241-TX-116. 
HNF-SD-WM-ER-711

Revision 0

Table D3-1. Composition of T1 Salt Cakes (2 Sheets).

\begin{tabular}{|c|c|c|c|c|c|c|}
\hline Analyte & $\begin{array}{c}\text { Tank } \\
241-\mathrm{T}-108^{\mathrm{a}} \\
(\mu \mathrm{g} / \mathrm{g})\end{array}$ & $\begin{array}{c}\text { Tank } \\
241-\mathrm{T}-109^{\mathrm{b}} \\
(\mu \mathrm{g} / \mathrm{g})\end{array}$ & $\begin{array}{c}\text { Tank } \\
241-\mathrm{TX}-116 \\
(\mu \mathrm{g} / \mathrm{g})^{\mathrm{c}, \mathrm{d}}\end{array}$ & $\begin{array}{c}\text { Relative } \\
\text { std dev } \\
\text { of mean } \\
(\%)\end{array}$ & $\begin{array}{c}\text { Average - } \\
\text { predicted } \\
\text { T1 salt } \\
\text { cake } \\
(\mu \mathrm{g} / \mathrm{g})\end{array}$ & $\begin{array}{c}\text { HDW } \\
\text { model } \\
\text { T1 SltCk } \\
(\mu \mathrm{g} / \mathrm{g})\end{array}$ \\
\hline $\mathrm{Ag}$ & $<7.96$ & 18.6 & NR & NA & $<13.3$ & NR \\
\hline $\mathrm{Al}$ & 2,290 & 1,250 & 1,720 & $17.2 \%$ & 1,750 & 140.1128 \\
\hline $\mathrm{Bi}$ & 605 & 170 & NR & $56.1 \%$ & 388 & $1,806.784$ \\
\hline $\mathrm{Ca}$ & 177 & 324 & NR & $29.3 \%$ & 251 & $2,116.939$ \\
\hline $\mathrm{Cd}$ & $<7.96$ & $<5$ & NR & $\mathrm{NA}$ & $<5^{f}$ & NR \\
\hline $\mathrm{Cl}$ & $<905$ & 341 & NR & NA & $341^{f}$ & $1,376.542$ \\
\hline $\mathrm{CO}_{3}$ & NR & 10,400 & 32,800 & $67.2 \%$ & 21,600 & $6,832.004$ \\
\hline $\mathrm{Cr}$ & 19.2 & 40 & 150 & $58.3 \%$ & 69.9 & 128.6514 \\
\hline $\mathrm{F}$ & 10,700 & 13,000 & 3,140 & $33.3 \%$ & 8,950 & 948.0084 \\
\hline $\mathrm{Fe}$ & 6,110 & 5,490 & 16,000 & $37.0 \%$ & 9,200 & $4,040.613$ \\
\hline $\mathrm{Hg}$ & NR & NR & NR & NA & $\mathrm{NR}$ & 0.601441 \\
\hline $\mathrm{K}$ & $<239$ & $<500$ & NR & NA & $<239^{\mathrm{f}}$ & 270.302 \\
\hline $\mathrm{La}$ & $<39.8$ & $<50$ & NR & NA & $<39.8^{\mathrm{f}}$ & 0 \\
\hline $\mathrm{Mn}$ & 182 & 1,030 & NR & $70.0 \%$ & 606 & 0 \\
\hline $\mathrm{Na}$ & 223,000 & 181,000 & 246,600 & $8.85 \%$ & 216,900 & $185,809.8$ \\
\hline $\mathrm{Ni}$ & $<15.9$ & $<20$ & NR & NA & $<18$ & 396.1703 \\
\hline $\mathrm{NO}_{2}$ & 6,210 & 492 & 210 & $84.8 \%$ & 2,300 & $5,525.867$ \\
\hline $\mathrm{NO}_{3}$ & 392,000 & 20,800 & 574,700 & $49.5 \%$ & 329,200 & $333,726.3$ \\
\hline $\mathrm{OH}$ & NR & NR & $\mathrm{NR}$ & NA & NR & $8,933.119$ \\
\hline $\mathrm{Pb}$ & 533 & 303 & NR & $27.5 \%$ & 418 & 0 \\
\hline $\mathrm{P}$ as $\mathrm{PO}_{4}$ & 125,000 & 246,000 & 13,500 & $52.4 \%$ & 128,200 & $70,614.37$ \\
\hline $\mathrm{Si}$ & 1,500 & 889 & NA & $25.6 \%$ & 1,200 & 287.0366 \\
\hline $\mathrm{S}$ as $\mathrm{SO}_{4}$ & 1,110 & 516 & 34,200 & $93.2 \%$ & 11,900 & $5,974.895$ \\
\hline $\mathrm{Sr}$ & 21.6 & $<10$ & NR & NA & $<15.8$ & 0 \\
\hline TOC & NR & NR & NR & NA & NR & $\begin{array}{c}1.34 \mathrm{E}-06 \\
(\mathrm{wt} \%)\end{array}$ \\
\hline $\mathrm{U}$ & 1,130 & $<500$ & 0.0052 & NA & $<543$ & $9,724.072$ \\
\hline $\mathrm{Zr}$ & 10.9 & 12.2 & NR & $5.63 \%$ & 11.6 & 19.18255 \\
\hline
\end{tabular}


HNF-SD-WM-ER-711

Revision 0

Table D3-1. Composition of T1 Salt Cakes (2 Sheets).

\begin{tabular}{|c|c|c|c|c|c|c|}
\hline Analyte & $\begin{array}{c}\text { Tank } \\
241-\mathrm{T}-108^{\mathrm{a}} \\
(\mu \mathrm{g} / \mathrm{g})\end{array}$ & $\begin{array}{c}\text { Tank } \\
241-\mathrm{T}-109^{\mathrm{b}} \\
(\mu \mathrm{g} / \mathrm{g})\end{array}$ & $\begin{array}{c}\text { Tank } \\
241-\mathrm{TX}-116 \\
(\mu \mathrm{g} / \mathrm{g})^{\mathrm{c}, \mathrm{d}}\end{array}$ & $\begin{array}{c}\text { Relative } \\
\text { std dev } \\
\text { of mean } \\
(\%)\end{array}$ & $\begin{array}{c}\text { Average } \\
\text { predicted } \\
\text { T1 salt } \\
\text { cake } \\
(\mu \mathrm{g} / \mathrm{g})\end{array}$ & $\begin{array}{c}\text { HDW } \\
\text { model } \\
\text { T1 SltCk } \\
(\mu \mathrm{g} / \mathrm{g})\end{array}$ \\
\hline $\begin{array}{c}\text { Radio- } \\
\text { nuclide }\end{array}$ & $\mu \mathrm{Ci} / \mathrm{g}$ & $\mu \mathrm{Ci} / \mathrm{g}$ & $\mu \mathrm{Ci} / \mathrm{g}$ & $\%$ & $\mu \mathrm{Ci} / \mathrm{g}$ & $\mu \mathrm{Ci} / \mathrm{g}$ \\
\hline${ }^{241} \mathrm{Am}$ & $<0.123$ & $\mathrm{NR}$ & $\mathrm{NR}$ & $\mathrm{NA}$ & $<0.123^{\mathrm{g}}$ & $4.67 \mathrm{E}-04$ \\
\hline${ }^{60} \mathrm{Co}$ & $<0.0133$ & $\mathrm{NR}$ & $\mathrm{NR}$ & $\mathrm{NA}$ & $<0.0162^{\mathrm{g}}$ & $5.77 \mathrm{E}-05$ \\
\hline${ }^{134} \mathrm{Cs}$ & $\mathrm{NR}$ & $\mathrm{NR}$ & 2.44 & $\mathrm{NA}$ & $0.0080^{\mathrm{g}}$ & $2.43 \mathrm{E}-06$ \\
\hline${ }^{137} \mathrm{Cs}$ & 2.00 & $\mathrm{NR}$ & 4.74 & $40.7 \%$ & $2.63^{\mathrm{g}}$ & 34.44064 \\
\hline${ }^{154} \mathrm{Eu}$ & $<0.0455$ & $\mathrm{NR}$ & $\mathrm{NR}$ & $\mathrm{NA}$ & $<0.0514^{\mathrm{g}}$ & 0.001026 \\
\hline${ }^{155} \mathrm{Eu}$ & $<0.0407$ & $\mathrm{NR}$ & $\mathrm{NR}$ & $\mathrm{NA}$ & $<0.0503^{\mathrm{g}}$ & 0.004959 \\
\hline $\begin{array}{c}\mathrm{Density} \\
(\mathrm{g} / \mathrm{mL})\end{array}$ & 2.35 & $1.55^{\mathrm{h}}$ & $\mathrm{NR}$ & $\mathrm{NA}$ & 1.95 & 1.742038 \\
\hline$\% \mathrm{H}{ }_{2} \mathrm{O}$ & $19.5 \%$ & $47.70 \%$ & $\mathrm{NR}$ & NA & $33.6 \%$ & $37.7268 \%$ \\
\hline
\end{tabular}

HDW $=$ Hanford Defined Waste

NA $=$ Not applicable

$\mathrm{NR}=$ Not reported

${ }^{a}$ Baldwin (1996)

Brown et al. (1996)

c Horton (1977)

${ }^{d}$ Silica-free basis due to the addition of diatomaceous earth to this tank

- Agnew et al. (1997a)

${ }^{\mathrm{f}}$ Since these analytes were not expected in this waste, the lower value was used instead of an average

${ }^{\mathrm{g}}$ Predicted $\mathrm{T} 1$ salt cake radionuclides are decayed to January 1,1994 . The radionuclides for tanks 241-T-108, 241-T-109, and 241-TX-116 are reported as of the date analyzed, therefore, the average predicted values may not match the reported values

${ }^{\mathrm{h}}$ The density reported by the 241-T-109 TCR (Brown et al. 1996) was not actually measured, but based on a HDW model Rev. 3 estimate (Agnew et al. 1996). 
The density reported for tank 241-T-108 is relatively high and reflects a particle density measurement, rather than a bulk density. The density of the predicted $\mathrm{T} 1$ salt cake was somewhat arbitrarily set to $1.7 \mathrm{~g} / \mathrm{ml}$ to avoid over-reporting of the waste components. T1 salt cake constitutes at roughly $31 \mathrm{vol} \%$ of the tank inventory, so the impact of the tank 241-T-108 high waste density could not be ignored. The selected value is in good agreement with the HDW model prediction for T1 salt cake.

\section{D3.4.2 Composition of 'T2 Salt Cake}

Post-1965 operation of the 242-T Evaporator resulted in $22,672 \mathrm{~kL}(5,990 \mathrm{kgal})$ of salt cake that is contained in 26 underground storage tanks in the S, SX, U, T, TX, and TY Tank Farms (Agnew et al. 1997a). The HDW model refers to this salt cake as T2 SltCk on a global basis or as SMMT2 when calculated by the SMM for an individual tank. The salt cake produced by the 242-T Evaporator from 1965 to 1976 will be referred to as $\mathrm{T} 2$ salt cake, hereafter, in this report. Ninety-one percent of the T2 salt cake is contained in the TX Tank Farm. All tanks containing T2 salt cake also contain other waste types.

Eight tanks containing T2 salt cake have been core sampled, 241-S-107, 241-U-102, 241-U-105, 241-U-107, 241-TX-107, 241-TX-116, 241-TY-102, and 241-TY-103. Only three of these tanks (241-U-102, 241-U-105 and 241-TX-116) have T2 salt cake layers large enough to differentiate it from other waste types in core sample data at the segment level.

$\mathrm{T} 2$ salt cake was formed in tanks 241-U-102 and 241-U-105 from 1975 through 1976 (Agnew et al. 1997a). Core sampling of tanks 241-U-102 and 241-U-105 was performed in early 1996. Based on the HDW model, segments 4, 5, and 6 for the two cores from tank 241-U-102 and segment 8 of two cores from tank 241-U-105 are expected to be representative of the T2 salt cake waste type. An independent determination of these levels is not possible because of a lack of solids volume measurements in this time period. Furthermore, a significant composition change between the expected $\mathrm{S} 2$ salt cake and $\mathrm{T} 2$ salt cake layers can not be seen in the core sample data. The recent analytical data should meet all Tri-Party Agreement requirements. Descriptions of the core sampling events and analytical data are available in the respective TCRs (Hu et al. 1997 and Brown and Franklin 1996).

T2 salt cake was deposited in tank 241-TX-116 between 1966 and 1971. The tank 241-TX-116 core sample was taken with the initial prototype of a rotary core sampler from 1976 to 1977 (Allen 1977). Sample recoveries were relatively poor. Additionally, analytical methods and quality assurance differed significantly from current practices. However, this sample event provides the only composition data for early production of the $\mathrm{T} 2$ salt cake waste type. Inclusion of an early T2 salt cake type is important since 242-T Evaporator feeds and operating practices changed over time.

The analytical data for tank 241-TX-116 are provided in a letter report (Horton 1977). Core segments 1 through 4 are expected to be representative T2 salt cake from the HDW 


\section{Revision 0}

model, and this is confirmed by vertical differences in the core sample results. It was necessary to correct the analytical results to a silicon-free basis since diatomaceous earth (92 percent $\mathrm{SiO}_{2}$ ) was added to tank 241-TX-116 in November of 1970 (Buckingham and Metz 1974). The silica from the diatomaceous earth had migrated into the top four core segments (approximately $203 \mathrm{~cm}$ [80 in.]) of the salt cake.

The composition data for tanks 241-U-102, 241-U-105, and 241-TX-116 are summarized in Table D3-2. The analytical results for tanks 241-U-102 and 241-U-105 are mass-weighted averages based on the mass of the partial core segment corresponding to each analytical result. Mass-weighted averages, rather than simple arithmetic averages, were calculated because the core segments were not of equal length and the mass of the partial core segments analyzed varied from approximately $30 \mathrm{~g}$ to $250 \mathrm{~g}$. Similarly, a mass-weighted average was created for the combination of the T2 salt cake in the two $U$ Farm tanks (81.5\% tank 241-U-102 and $18.5 \%$ tank 241-U-105). The analytical results for tank 241-TX-116 core segments were simply averaged since the core segments were of equal length. The T2 salt cake prediction is the arithmetic average of the U Tank Farm and tank 241-TX-116 concentrations. The data for tank 241-TX-116 were intentionally given more emphasis (50 percent of the predicted concentration) in the generalized T2 salt cake prediction as it represents an operating period that is more applicable to the TX Tank Farm. The global HDW model composition for T2 salt cake (T2 SltCk) is included in the Table D3-2 for comparison.

The use of the composition data from tanks 241-U-102, 241-U-105; and 241-TX-116 to represent the composition of other $\mathrm{T} 2$ salt cakes should be viewed only as an approximation. None of these three tanks had undergone salt well pumping at the time of the respective core samples. In the case of tank 241-TX-117, these data are being applied to a salt cake which has been salt well pumped and has collapsed to a reduced volume as the result of the removal of interstitial Iiquid. Additionally, the T2 salt cake projected by the HDW model in tanks 241-U-102 and 241-U-105 could be erroneous if the transfers were TX Tank Farm supernatants (i.e., saturated salt solutions that had already cooled and would not form additional salt cake) rather than actual evaporator bottoms. 
HNF-SD-WM-ER-711

Revision 0

Table D3-2. Composition of T2 Salt Cakes (2 Sheets).

\begin{tabular}{|c|c|c|c|c|c|c|}
\hline Analyte & $\begin{array}{c}241-\mathrm{U}-102 \\
\text { T2 salt cake } \\
\text { wt. avg., } \\
(\mu \mathrm{g} / \mathrm{g})\end{array}$ & $\begin{array}{c}241-\mathrm{U}-105 \\
\text { T2 salt cake } \\
\text { wt. avg.a,c } \\
(\mu \mathrm{g} / \mathrm{g})\end{array}$ & $\begin{array}{l}\text { U Tank } \\
\text { Farm } \\
\text { T2 salt } \\
\text { cake } \\
\text { wt. avg. }{ }^{a} \\
(\mu \mathrm{g} / \mathrm{g})\end{array}$ & $\begin{array}{c}241-\mathrm{TX}-116 \\
\text { T2 salt cake } \\
\text { mean }^{\mathrm{d}, \mathrm{e}} \\
(\mu \mathrm{g} / \mathrm{g})\end{array}$ & $\begin{array}{c}\mathrm{T} 2 \text { salt } \\
\text { cake } \\
\text { prediction } \\
(\mu \mathrm{g} / \mathrm{g})\end{array}$ & $\begin{array}{c}\text { HDW } \\
\text { T2 SltCk } \\
(\mu \mathrm{g} / \mathrm{g})\end{array}$ \\
\hline $\mathrm{Ag}$ & 11.6 & 19.7 & 13.1 & NR & 13.1 & NR \\
\hline $\mathrm{Al}$ & 18,000 & 12,900 & 17,100 & 38,000 & 27,500 & 17,912 \\
\hline $\mathrm{Bi}$ & $<70.5$ & $<47.2$ & $<66.2$ & $\mathrm{NR}$ & $<66.2$ & 220.81 \\
\hline $\mathrm{Ca}$ & 308 & 253 & 298 & NR & 298 & 1,462 \\
\hline $\mathrm{Cd}$ & $<5.94$ & 12.8 & $<7.21$ & NR & $<7.21$ & NR \\
\hline $\mathrm{Cl}$ & 5,100 & 5,790 & 5,230 & NR & 5,230 & $3,327.8$ \\
\hline $\mathrm{CO}_{3}$ & 53,500 & 36,500 & 50,300 & 58,000 & 54,200 & 17,093 \\
\hline $\mathrm{Cr}$ & 2,310 & 2,100 & 2,270 & 353 & 1,310 & 4259.6 \\
\hline $\mathrm{F}$ & $<125$ & 1,110 & $<307$ & 3,540 & $<1,920$ & 930.79 \\
\hline $\mathrm{Fe}$ & 391 & 2,270 & 737 & 23,900 & 12,300 & 620.58 \\
\hline $\mathrm{Hg}$ & $\mathrm{NR}$ & NR & NA & NR & NA & 1.1338 \\
\hline $\mathrm{K}$ & 1750 & 1,470 & 1,700 & $\mathrm{NR}$ & 1,700 & 1060.7 \\
\hline $\mathrm{La}$ & $<35.2$ & 29.7 & $<34.2$ & NR & $<34.2$ & $1.0 \mathrm{E}-04$ \\
\hline $\mathrm{Mn}$ & 123 & 743 & 237 & NR & 237 & 160.31 \\
\hline $\mathrm{Na}$ & 262,600 & 220,500 & 254,800 & 166,700 & 210,800 & 192,764 \\
\hline $\mathrm{Ni}$ & 91.5 & 89.5 & 91.1 & NR & 91.1 & 405.82 \\
\hline $\mathrm{NO}_{2}$ & 56,700 & 40,100 & 53,600 & 7,840 & 30,700 & $.46,096$ \\
\hline $\mathrm{NO}_{3}$ & 284,700 & 395,700 & 305,200 & 308,700 & 306,946 & 268,197 \\
\hline $\mathrm{OH}$ & NR & $\mathrm{NR}$ & NA & $\mathrm{NA}$ & NA & 68,079 \\
\hline $\mathrm{Pb}$ & $<119$ & 214 & $<136$ & NR & $<136$ & 109.91 \\
\hline $\mathrm{P}$ as $\mathrm{PO}_{4}$ & 5,050 & 14,100 & 6,720 & 8,620 & 7,670 & $7,707.9$ \\
\hline $\mathrm{Si}$ & 152 & 232 & 167 & NR & 167 & $1,817.7$ \\
\hline $\mathrm{S}$ as $\mathrm{SO}_{4}$ & 17,900 & 8,350 & 16,200 & 16,400 & 16,300 & 13,823 \\
\hline $\mathrm{Sr}$ & $<7.04$ & $<4.72$ & $<6.61$ & NR & $<6.61$ & 0 \\
\hline TOC & 8,810 & 11,000 & 9,210 & $\mathrm{NR}$ & 9,210 & 5,191 \\
\hline$U$ & $<353$ & 545 & $<388$ & NR & $<388$ & $2,174.3$ \\
\hline $\mathrm{Zr}$ & 10.8 & 45.4 & 17.2 & NR & 17.2 & 14.707 \\
\hline
\end{tabular}


HNF-SD-WM-ER-711

Revision 0

Table D3-2. Composition of T2 Salt Cakes (2 Sheets).

\begin{tabular}{|c|c|c|c|c|c|c|}
\hline Analyte & $\begin{array}{c}\text { 241-U-102 } \\
\text { T2 salt cake } \\
\text { wt. avg., } \\
(\mu \mathrm{g} / \mathrm{g})\end{array}$ & $\begin{array}{c}\text { 241-U-105 } \\
\text { T2 salt cake } \\
\text { wt. avg., } \\
(\mu \mathrm{g} / \mathrm{g})\end{array}$ & $\begin{array}{c}\text { U Tank } \\
\text { Farm } \\
\text { T2 salt } \\
\text { cake } \\
\text { wt. avg. } \\
(\mu \mathrm{g} / \mathrm{g})\end{array}$ & $\begin{array}{c}\text { 241-TX-116 } \\
\text { T2 salt cake } \\
\text { mean }^{\mathrm{d}, \mathrm{e}} \\
(\mu \mathrm{g} / \mathrm{g})\end{array}$ & $\begin{array}{c}\text { T2 salt } \\
\text { cake } \\
\text { prediction }^{\mathrm{f}} \\
(\mu \mathrm{g} / \mathrm{g})\end{array}$ & $\begin{array}{c}\text { HDW } \\
\text { T2 SltCkg } \\
(\mu \mathrm{g} / \mathrm{g})\end{array}$ \\
\hline \multicolumn{6}{|l|}{}
\end{tabular}

HDW $=$ Hanford Defined Waste

$\mathrm{NA}=$ Not applicabie

NR $=$ Not reported

${ }^{a}$ Weighted average based on the weight of each partial core segment analyzed

${ }^{\mathrm{b}} \mathrm{Hu}$ et al. (1997)

${ }^{\mathrm{C}}$ Brown and Franklin (1996)

${ }^{d}$ Silica-free basis due to the addition of diatomaceous earth to this tank

e Horton (1977)

${ }^{\mathrm{f}}$ Average of U Tank Farm and tank 241-TX-116 data

${ }^{8}$ Agnew et al. (1997)

${ }^{\text {h }}$ Decayed to January 1, 1994

${ }^{\mathrm{i}}$ A simple average is used for the density.

\section{D3.4.3 Composition of Diatomaceous Earth}

Approximately $40.8 \mathrm{MT}$ of diatomaceous earth was added to tank 241-TX-117 in January 1971 to demonstrate absorption of free liquids in waste tanks (Buckingham and Metz 1974). Diatomaceous earth is the siliceous skeletal remains of single-cell algae. The composition of the diatomaceous earth added to tank 241-TX-117 is provided in Table D3-3. 
Table D3-3. Diatomaceous Earth Addition to 241-TX-117.

\begin{tabular}{|c|c|c|c|}
\hline Chemical compound & Weight percent & Element & Element added (kg) \\
\hline $\mathrm{SiO}_{2}$ & 92.3 & $\mathrm{Si}$ & 17,600 \\
\hline $\mathrm{Al}_{2} \mathrm{O}_{3}$ & 1.1 & $\mathrm{Al}$ & 238 \\
\hline $\mathrm{Fe}_{2} \mathrm{O}_{3}$ & 2.0 & $\mathrm{Fe}$ & 571 \\
\hline $\mathrm{CaO}$ & 0.9 & $\mathrm{Ca}$ & 263 \\
\hline $\mathrm{MgO}$ & 0.4 & $\mathrm{Mg}$ & 98 \\
\hline Loss on ignition & 3.1 & Unknown & 1,265 \\
\hline
\end{tabular}

\section{D3.5 PREDICTED INVENTORY FOR TANK 241-TX-117}

The chemical and radionuclide inventory of tank 241-TX-117 can be estimated from the T1 salt cake, and T2 salt cake volumes (746 kL [197 kgal], and 1,514 kL [400 kgal], respectively), densities $(1.7 \mathrm{~g} / \mathrm{mL})$ and the average of chemical/radionuclide concentrations calculated for the 242-T salt cake wastes that have been analyzed. The chemicals included in the diatomaceous earth $(110 \mathrm{~kL}$ [29 kgal]) were previously calculated in Table D3-3. The resulting inventories are provided in Table D3-4. The inventories estimated by the HDW model (Agnew et al. 1997a) are included in the table for comparison.

Table D3-4. Estimated Chemical and Radionuclide Inventory for Tank 241-TX-117. (3 sheets)

\begin{tabular}{|c|c|c|c|c|c|}
\hline Analyte & $\begin{array}{c}\text { T1 salt cake } \\
\text { layer } \\
\text { inventory } \\
(\mathrm{kg})\end{array}$ & $\begin{array}{c}\text { T2 salt cake } \\
\text { layer } \\
\text { inventory } \\
(\mathrm{kg})\end{array}$ & $\begin{array}{c}\text { Diatomaceous } \\
\text { Earth }^{\mathrm{c}} \\
(\mathrm{kg})\end{array}$ & $\begin{array}{c}\text { Predicted } \\
241-\mathrm{TX}-117 \\
\text { inventory } \\
(\mathrm{kg})\end{array}$ & $\begin{array}{c}\text { HDW } \\
\text { model } \\
\text { inventory } \\
(\mathrm{kg})\end{array}$ \\
\hline $\mathrm{Ag}$ & $<16.8$ & 33.8 & $\mathrm{NR}$ & $<50.6$ & $\mathrm{NR}$ \\
\hline $\mathrm{Al}$ & 2,220 & 70,900 & 238 & 73,400 & 37,400 \\
\hline $\mathrm{Bi}$ & 491 & $<170$ & $\mathrm{NR}$ & $<661$ & 2,840 \\
\hline $\mathrm{Ca}$ & 318 & 766 & 263 & 1,350 & 4,500 \\
\hline $\mathrm{Cd}$ & $<6.34$ & 18.5 & $\mathrm{NR}$ & $<24.9$ & $\mathrm{NR}$ \\
\hline $\mathrm{Cl}$ & 432 & 13,500 & $\mathrm{NR}$ & 13,900 & 8,960 \\
\hline $\mathrm{CO} 3$ & 27,300 & 139,400 & $\mathrm{NR}$ & 166,800 & 30,900 \\
\hline $\mathrm{Cr}$ & 88.6 & 3,380 & $\mathrm{NR}$ & 3,470 & 5,280 \\
\hline $\mathrm{F}$ & 11,300 & $<4,950$ & $\mathrm{NR}$ & $<16,300$ & 3,440 \\
\hline $\mathrm{Fe}$ & 11,700 & 31,700 & 571 & 44,000 & 6,310 \\
\hline $\mathrm{Hg}$ & $\mathrm{NR}$ & $\mathrm{NR}$ & $\mathrm{NR}$ & $\mathrm{NA}$ & 3.75 \\
\hline
\end{tabular}


HNF-SD-WM-ER-711

Revision 0

Table D3-4. Estimated Chemical and Radionuclide Inventory for Tank 241-TX-117. (3 sheets)

\begin{tabular}{|c|c|c|c|c|c|}
\hline Analyte & $\begin{array}{l}\text { T1 salt cake } \\
\text { layer } \\
\text { inventory } \\
(\mathrm{kg})\end{array}$ & $\begin{array}{l}\text { T2 salt cake } \\
\text { layer } \\
\text { inventory } \\
(\mathrm{kg})\end{array}$ & $\begin{array}{c}\text { Diatomaceous } \\
\text { Earth }^{\circ} \\
(\mathrm{kg})\end{array}$ & \begin{tabular}{|c|} 
Predicted \\
$241-\mathrm{TX}-117$ \\
inventory \\
$(\mathrm{kg})$ \\
\end{tabular} & $\begin{array}{c}\text { HDW } \\
\text { model } \\
\text { inventory } \\
(\mathrm{kg}) \\
\end{array}$ \\
\hline $\mathrm{K}$ & $<303$ & 4,370 & NR & $<4,670$ & 2,520 \\
\hline $\mathrm{La}$ & $<50.5$ & $<88.1$ & NR & $<139$ & $1.39 \mathrm{E}-04$ \\
\hline $\mathrm{Mn}$ & 768 & 611 & NR & 1,380 & 139 \\
\hline $\mathrm{Na}$ & 274,900 & 542,500 & NR & 817,400 & 534,000 \\
\hline $\mathrm{Ni}$ & $<22.8$ & 235 & NR & $<257$ & 908 \\
\hline $\mathrm{NO}_{2}$ & 2,920 & 79,100 & NR & 82,000 & 96,200 \\
\hline $\mathrm{NO}_{3}$ & 417,300 & 790,000 & $\mathrm{NR}$ & $1.207 \mathrm{E}+06$ & 725,000 \\
\hline $\mathrm{OH}$ & 8,120 & 84,600 & NR & 92,800 & 139,000 \\
\hline $\mathrm{Pb}$ & 530 & $<351$ & NR & $<881$ & 305 \\
\hline $\mathrm{PO}_{4}$ & 162,400 & 19,700 & $\mathrm{NR}$ & 182,200 & 103,000 \\
\hline $\mathrm{Si}$ & 1,510 & 430 & 17,600 & 19,600 & 19,700 \\
\hline $\mathrm{SO}_{4}$ & 15,100 & 41,900 & NR & 57,100 & 31,300 \\
\hline $\mathrm{Sr}$ & $<20.0$ & $<17.0$ & NR & $<37.0$ & 0 \\
\hline TOC & NR & 23,700 & $\mathrm{NR}$ & 23,700 & 4,060 \\
\hline $\mathrm{U}$ & $<689$ & $<999$ & NR & $<1,690$ & 15,200 \\
\hline $\mathrm{Zr}$ & 14.6 & 44.3 & NR & 58.9 & 69.7 \\
\hline $\begin{array}{l}\text { Radio- } \\
\text { nuclided }^{d}\end{array}$ & $\begin{array}{c}\text { T1 Salt } \\
\text { cake layer }^{\mathrm{a}} \\
\text { (Ci) }\end{array}$ & $\begin{array}{c}\text { T2 Salt } \\
\text { cake layer } \\
\text { (Ci) }\end{array}$ & $\begin{array}{c}\text { Diatomaceous } \\
\text { Earth }^{c}\end{array}$ & $\begin{array}{c}\text { Predicted } \\
241-\mathrm{TX}-117 \\
\text { inventory } \\
\text { (Ci) } \\
\end{array}$ & $\begin{array}{l}\text { HDW } \\
\text { model } \\
\text { inventory } \\
(\mathrm{Ci})\end{array}$ \\
\hline${ }^{241} \mathrm{Am}$ & $<156$ & $<78,000$ & NA & $<78,200$ & 39.7 \\
\hline${ }^{60} \mathrm{Co}$ & $<20.5$ & $<365$ & NA & $<386$ & 26.2 \\
\hline${ }^{134} \mathrm{Cs}$ & 10.2 & 2.48 & NA & 12.7 & 2.02 \\
\hline${ }^{137} \mathrm{Cs}$ & 3,340 & 286,300 & NA & 289,600 & 315,000 \\
\hline${ }^{154} \mathrm{Eu}$ & $<65.2$ & $<1,280$ & NA & $<1,350$ & 413 \\
\hline
\end{tabular}


HNF-SD-WM-ER-711

Revision 0

Table D3-4. Estimated Chemical and Radionuclide Inventory for Tank 241-TX-117. (3 sheets)

\begin{tabular}{|c|c|c|c|c|c|}
\hline $\begin{array}{c}\text { Radio- } \\
\text { nuclide }^{\mathrm{d}}\end{array}$ & $\begin{array}{c}\mathrm{T} 1 \text { salt cake } \\
\text { layer }^{\mathrm{a}} \\
(\mathrm{Ci})\end{array}$ & $\begin{array}{c}\mathrm{T} 2 \text { salt cake } \\
\text { layer }^{\mathrm{b}} \\
(\mathrm{Ci})\end{array}$ & $\begin{array}{c}\text { Diatomaceous } \\
\text { Earth }^{\mathrm{c}}\end{array}$ & $\begin{array}{c}\text { Predicted } \\
241-\mathrm{TX}-117 \\
\text { inventory } \\
(\mathrm{Ci})\end{array}$ & $\begin{array}{c}\mathrm{HDW} \\
\text { model } \\
\text { inventory } \\
(\mathrm{Ci})\end{array}$ \\
\hline${ }^{155} \mathrm{Eu}$ & $<63.8$ & $<2,690$ & NA & $<2,760$ & 162 \\
\hline
\end{tabular}

HDW $=$ Hanford Defined Waste

NA $=$ Not applicable

$\mathrm{NR}=$ Not reported

"Based on the T1 salt cake prediction in Table D3-1.

${ }^{\mathrm{b}}$ Based on the T2 salt cake prediction in Table D3-2.

- Based on the diatomaceous earth composition provided in Table D3-3.

d Radionuclides decayed to January 1, 1994.

\section{D3.6 COMPARISON OF TANK 241-TX-117 INVENTORY ESTIMATES}

The lack of sample-based inventory data adds considerable uncertainty to estimation of chemical and radionuclide inventories for tank 241-TX-117. The use of waste composition data from tanks $241-\mathrm{T}-108,241-\mathrm{T}-109,241-\mathrm{TX}-116,241-\mathrm{U}-102$, and 241-U-105 to represent the wastes in tank 241-TX-117 is a reasonable approach in the absence of analytical data. However, it should be noted that the operating history of tank 241-TX-117 is different from any other Hanford Site tank containing similar waste types. Estimation based on compositions measured in other tanks should be regarded as only an approximation.

The tank 241-TX-117 inventories predicted by the HDW model and the estimate based on waste analyses in other tanks are generally of the same order of magnitude, although the HDW model inventories are generally somewhat lower. Part of the explanation for this difference may be that the HDW model calculated density for the tank 241-TX-117 T2 sait cake is $1.44 \mathrm{~g} / \mathrm{cc}$ based on the sodium, aluminum, and hydroxide concentrations. This HDW calculated density is often much lower than is generally found when salt cakes are analyzed. The calculated density is used in determining the HDW model inventory for all analytes. Additionally, the HDW model reduced the T2 salt cake inventory by $356 \mathrm{~kL}$ ( $94 \mathrm{kgal}$ ) based on the quantity of interstitial liquid removed.

Aluminum. The estimated aluminum inventory is 1.96 times higher than that predicted by the HDW model. Part of this difference is attributable to the low T2 salt cake density calculated by the HDW model $(1.44 \mathrm{~g} / \mathrm{cc})$, as compared to the $1.7 \mathrm{~g} / \mathrm{mL}$ estimated from analytical data for T2 salt cakes, and the lower T2 salt cake volume used by the HDW model. The tank 241-TX-116 analytical results show a much higher aluminum concentration and Anderson (1990) indicates processing of a substantial volume of aluminum coating 
wastes in the 1967-1968 time period. The estimated aluminum inventory will be used for the best-basis inventory.

Carbonate and Hydroxide. The estimated tank 241-TX-117 carbonate inventory is 5.4 times the HDW model inventory. The hydroxide ion in Hanford waste tanks is converted to carbonate by the absorption of carbon dioxide from the ambient air. One mole of absorbed carbon dioxide will react with two moles of hydroxide ion to form one mole of carbonate ion. The rate is difficult to model at best, and is accelerated by the use of airlift circulators installed in many Hanford underground storage tanks. Conversion of $77,000 \mathrm{~kg}$ of hydroxide to carbonate would account for the difference. The HDW model does not account for the absorption of carbon dioxide from the atmosphere.

Fluoride. The estimated fluoride inventory is 4.7 times that predicted by the HDW model. This is possibly the result of the HDW model assumptions that sodium fluoride is the only chemical compound containing fluoride and that it does not precipitate. The formation of insoluble fluoride compounds (such as sodium fluorophosphate) may be causing some fluoride to precipitate and remain in the tank.

Iron. The estimated iron inventory is skewed by the high iron concentration $(2.4 \mathrm{wt} \%$ on silicon-free basis) reported for tank 241-TX-116 T2 salt cake. A later analysis of the tank 241-TX-116 salt cake (Schulz 1980) indicated very little insoluble material. The high iron concentration is not likely for a salt cake since iron is insoluble in alkaline solutions and significant iron concentration would not be expected in the evaporator feed solutions. Therefore, the HDW model iron inventory will be used for the best-basis.

Nitrate. The estimated nitrate inventory is 1.7 times that predicted by the HDW model. Much of the HDW model salt cake inventory is predicted by the SMM, and it is, therefore, difficult to determine the specific causes of this discrepancy. The global HDW model T1 and T2 salt cake concentrations (see Tables D3-1 and D3-2) are very reasonable, indicating that either the problem lies within the SMM model or that some feed inputs have been missed.

Phosphate. The estimated phosphate inventory is 1.8 times that predicted by the HDW model. Most of the phosphate (roughly 90 percent) is associated with the T1 salt cake layer. The discrepancy is primarily due to the different phosphate concentrations predicted for $\mathrm{T} 1$ salt cake.

Sodium. The predicted HDW sodium inventory is about 65 percent that predicted from analytical data for other $\mathrm{T} 1$ and $\mathrm{T} 2$ salt cake tanks. The waste density predicted by the HDW model for the T2 salt slurry is $1.49 \mathrm{~g} / \mathrm{cc}$, which is 13 percent below that normally expected for a salt cake. The total volume of salt cake predicted by the HDW model is $356 \mathrm{~kL}$ (94 kgal) less, which could explain another 16 percent of the difference. The remainder of the difference is the result of the low sodium concentration predicted for the T2 salt cake layer by the SMM. The global HDW model T2 salt cake sodium concentration is 


\section{HNF-SD-WM-ER-711 \\ Revision 0}

very reasonable (see Table D3-2). Either there is an internal problem in the SMM model calculations or some feed inputs have been missed.

Total Hydroxide. Once the best-basis inventories were determined, the hydroxide inventory was calculated by performing a charge balance with the valences of the other analytes. In some cases, this approach requires that other analyte (e.g., sodium or nitrate) inventories be adjusted to achieve the charge balance. During such adjustments, the number of significant figures is not increased. The charge balance approach is consistent with that used by Agnew et al. (1997a). The revised total hydroxide inventory based on the best-basis inventory is $163,000 \mathrm{~kg}$, which is about 17 percent higher than the HDW model estimate. The difference results from the generally higher chemical inventories indicated by analytical data for $\mathrm{T} 1$ and $\mathrm{T} 2$ salt cake tanks.

Cesium-137 and Strontium-90. The heat load for tank 241-TX-117 was not estimated (Kummerer 1995) due to a lack of waste and vapor space temperature data. The lack of a heat load estimate makes evaluation of validity of ${ }^{137} \mathrm{Cs}$ and ${ }^{90} \mathrm{Sr}$ inventories difficult. The HDW ${ }^{137} \mathrm{Cs}$ inventory is only 9 percent higher than predicted from analytical data from other waste tanks. To be conservative, the higher HDW model inventory will be used as the best-basis. The HDW model inventory for ${ }^{90} \mathrm{Sr}$ will also be used for the best-basis as insufficient ${ }^{90} \mathrm{Sr}$ analytical data are available for the salt cakes. Tank 241-TX-117 did not store complexed wastes (waste transactions designated as EVT, Agnew et al. 1997b) containing relatively high ${ }^{90} \mathrm{Sr}$ concentrations during $1974-1976$, so the $86,000 \mathrm{Ci}{ }^{90} \mathrm{Sr} \mathrm{HDW}$ inventory is not unreasonably low. 
HNF-SD-WM-ER-711

Revision 0

\section{D4.0 DEFINE THE BEST-BASIS AND ESTABLISH COMPONENT INVENTORIES}

Information about chemical, radiological, and/or physical properties is used to perform safety analyses, engineering evaluations, and risk assessment associated with waste management activities, as well as regulatory issues. These activities include overseeing tank farm operations and identifying, monitoring, and resolving safety issues associated with these operations and with the tank wastes. Disposal activities involve designing equipment, processes and facilities for retrieving wastes and processing them into a form that is suitable for long-term storage.

Chemical and radiological inventory information are generally derived using three approaches: (1) component inventories are estimated using the results of sample analyses, (2) component inventories are predicted using the HDW model based on process knowledge and historical information, or (3) a tank-specific process estimate is made based on process flowsheets, reactor fuel data, essential material usage, and other operating data.

An effort is underway to provide waste inventory estimates that will serve as the standard characterization for the various waste management activities (Hodgson and LeClair 1996). As part of this effort, an evaluation of available information for tank 241-TX-117 was performed including the following:

- Waste transactions and operating data to confirm that only 242-T Evaporator salt cakes and diatomaceous earth were expected in this tank

- Composition data from three waste tanks (241-T-108 [Brown et al. 1996], 241-T-109 [Brown et al. 1996], and 241-TX-116 [Horton 1977]) that are expected to have similar T1 salt cake compositions, and tbree waste tanks (241-U-102 [Hu et al. 1997], 241-U-105 [Brown and Franklin 1996], and 241-TX-116 [Horton 1977]) that are expected to have similar $T 2$ salt cake compositions

- The quantity and composition of diatomaceous earth added to the tank

- An inventory estimate generated by the HDW model (Agnew et al. 1997a).

Based on this evaluation, a best-basis inventory was developed. No analytical data are available for the salt cake remaining in tank 241-TX-117 because no samples have been taken. The estimated inventory was, therefore, based on the composition of: the T1 salt cakes in tanks 241-T-108, 241-T-109, and 241-TX-116, and the T2 salt cakes in tanks 241-U-102, 241-U-105, and 241-TX-116 since the wastes in these tanks have actually been analyzed. The HDW model inventories were used when no other data were available or when analytical data were suspect.

The waste in tank $241-\mathrm{TX}-117$ consists of $2,260 \mathrm{~kL}$ ( $597 \mathrm{kgal})$ of T1 and T2 salt cake produced by the $242-\mathrm{T}$ Evaporator and $110 \mathrm{~kL}$ ( $29 \mathrm{kgal}$ ) of diatomaceous earth. The 


\section{HNF-SD-WM-ER-711 \\ Revision 0}

best-basis inventory for tank 241-TX-117 is presented in Tables D4-1 and D4-2. The inventory values reported in Tables D4-1 and D4-2 are subject to change. Refer to the Tank Characterization Database (TCD) for the most current inventory values.

Best-basis tank inventory values are derived for 46 key radionuclides (as defined in Section 3.1 of Kupfer et al. 1997), all decayed to a common report date of January 1, 1994. Often, waste sample analyses have only reported ${ }^{90} \mathrm{Sr},{ }^{137} \mathrm{Cs}$, ${ }^{239 / 240} \mathrm{Pu}$, and total uranium, or (total beta and total alpha) while other key radionuclides such as ${ }^{60} \mathrm{Co},{ }^{99} \mathrm{Tc},{ }^{129} \mathrm{I},{ }^{154} \mathrm{Eu},{ }^{155} \mathrm{Eu}$, and ${ }^{241} \mathrm{Am}$, etc., have been infrequently reported. For this reason it has been necessary to derive most of the 46 key radionuclides by computer models. These models estimate radionuclide activity in batches of reactor fuel, account for the split of radionuclides to various separations plant waste streams, and track their movement with tank waste transactions. (These computer models are described in Kupfer et al. 1997, Section 6.1 and in Watrous and Wootan 1997.) Model generated values for radionuclides in any of 177 tanks are reported in the HDW Rev. 4 model results (Agnew et al. 1997a). The best-basis value for any one analyte may be either a model result or a sample or engineering assessment-based result if available. (No attempt has been made to ratio or normalize model results for all 46 radionuclides when values for measured radionuclides disagree with the model.) For a discussion of typical error between model derived values and sample derived values, see Kupfer et al. 1997; Section 6.1.10.

Table D4-1. Best-Basis Inventory Estimates for Nonradioactive Components in Tank 241-TX-117 (Effective May 31, 1997). (2 Sheets)

\begin{tabular}{|c|c|c|l|}
\hline Analyte & $\begin{array}{c}\text { Total inventory } \\
(\mathrm{kg})\end{array}$ & $\begin{array}{c}\text { Basis } \\
(\mathrm{S}, \mathrm{M}, \mathrm{E}, \text { or } \mathrm{C})^{1}\end{array}$ & Comment \\
\hline $\mathrm{Al}$ & 73,400 & $\mathrm{E}$ & \\
\hline $\mathrm{Bi}$ & $<661$ & $\mathrm{E}$ & \\
\hline $\mathrm{Ca}$ & 1,350 & $\mathrm{E}$ & \\
\hline $\mathrm{Cl}$ & 13,900 & $\mathrm{E}$ & \\
\hline $\mathrm{TIC}$ as CO & 166,800 & $\mathrm{E}$ & \\
\hline $\mathrm{Cr}$ & 3,470 & $\mathrm{E}$ & \\
\hline $\mathrm{F}$ & $<16,300$ & $\mathrm{E}$ & \\
\hline $\mathrm{Fe}$ & 6,310 & $\mathrm{M}$ & \\
\hline $\mathrm{Hg}$ & 3.75 & $\mathrm{M}$ & \\
\hline $\mathrm{K}$ & $<4,670$ & $\mathrm{E}$ & \\
\hline $\mathrm{La}$ & $1.39 \mathrm{E}-04$ & $\mathrm{M} / \mathrm{E}$ & \\
\hline $\mathrm{Mn}$ & 1,380 & $\mathrm{E}$ & \\
\hline $\mathrm{Na}$ & 817,000 & $\mathrm{E}$ & \\
\hline $\mathrm{Ni}$ & $<257$ & $\mathrm{E}$ & \\
\hline
\end{tabular}




\section{Revision 0}

Table D4-1. Best-Basis Inventory Estimates for Nonradioactive Components in Tank 241-TX-117 (Effective May 31, 1997). (2 Sheets)

\begin{tabular}{|c|c|c|l|}
\hline Analyte & $\begin{array}{c}\text { Total inventory } \\
(\mathrm{kg})\end{array}$ & $\begin{array}{c}\text { Basis } \\
(\mathrm{S}, \mathrm{M}, \mathrm{E}, \text { or } \mathrm{C})^{1}\end{array}$ & Comment \\
\hline $\mathrm{NO}_{2}$ & 82,000 & $\mathrm{E}$ & \\
\hline $\mathrm{NO}_{3}$ & $1.21 \mathrm{E}+06$ & $\mathrm{E}$ & $\begin{array}{l}\text { Concentration varies significantly } \\
\text { between T1 salt cakes. }\end{array}$ \\
\hline $\mathrm{OH}_{\text {ToxAL }}$ & 157,000 & $\mathrm{C}$ & Estimated by ion charge balance. \\
\hline $\mathrm{Pb}$ & $<881$ & $\mathrm{E}$ & \\
\hline $\mathrm{P}$ as $\mathrm{PO}_{4}$ & 128,000 & $\mathrm{E}$ & $\begin{array}{l}\text { Concentration varies significantly } \\
\text { between } \mathrm{T} 1 \text { salt cakes. }\end{array}$ \\
\hline $\mathrm{Si}$ & 19,600 & $\mathrm{E}$ & \\
\hline $\mathrm{S}$ as $\mathrm{SO}_{4}$ & 57,100 & $\mathrm{E}$ & \\
\hline $\mathrm{Sr}$ & $<37$ & $\mathrm{E}$ & \\
\hline $\mathrm{TOC}$ & 23,700 & $\mathrm{E}$ & \\
\hline $\mathrm{U}_{\text {ToTAI }}$ & $<1,690$ & $\mathrm{E}$ & \\
\hline $\mathrm{Zr}$ & 59 & $\mathrm{E}$ & \\
\hline $\mathrm{S}$ & & & \\
\hline
\end{tabular}

${ }^{1} \mathrm{~S}=$ Sample-based

$M=$ Hanford Defined Waste model-based, Agnew et al. (1997a)

$\mathrm{E}=$ Engineering assessment-based

$\mathrm{C}=$ Calculated by charge balance; includes oxides as hydroxides, not including $\mathrm{CO}_{3}, \mathrm{NO}_{2}, \mathrm{NO}_{3}, \mathrm{PO}_{4}, \mathrm{SO}_{4}$, and $\mathrm{SiO}_{3}$. 


\section{Revision 0}

Table D4-2. Best-Basis Inventory Estimates for Radioactive Components in Tank 241-TX-117, Decayed to January 1, 1994 (Effective May 31, 1997). (2 sheets)

\begin{tabular}{|c|c|c|c|}
\hline Analyte & $\begin{array}{l}\text { Total inventory } \\
\text { (Ci) }\end{array}$ & $\begin{array}{c}\text { Basis } \\
(\mathrm{S}, \mathrm{M}, \text { or } \mathrm{E})^{\mathrm{I}}\end{array}$ & Comment \\
\hline${ }^{3} \mathrm{H}$ & 168 & $\mathrm{M}$ & \\
\hline${ }^{14} \mathrm{C}$ & 24.4 & $\mathrm{M}$ & \\
\hline${ }^{59} \mathrm{Ni}$ & 2.66 & $\mathrm{M}$ & \\
\hline${ }^{60} \mathrm{Co}$ & 26.2 & $\mathrm{E} / \mathrm{M}$ & \\
\hline${ }^{63} \mathrm{Ni}$ & 255 & $M$ & \\
\hline${ }^{79} \mathrm{Se}$ & 2.53 & $M$ & \\
\hline${ }^{90} \mathrm{Sr}$ & 86,000 & $\mathrm{M}$ & \\
\hline${ }^{90} \mathrm{Y}$ & 86,100 & $\mathrm{M}$ & \\
\hline${ }^{93} \mathrm{Zr}$ & 12.4 & $\mathrm{M}$ & \\
\hline${ }^{93 \mathrm{~m}} \mathrm{Nb}$ & 9.04 & $\mathrm{M}$ & \\
\hline${ }^{99} \mathrm{Tc}$ & 174 & $\mathrm{M}$ & \\
\hline${ }^{106} \mathrm{Ru}$ & 0.00425 & M & \\
\hline${ }^{113 \mathrm{~m}} \mathrm{Cd}$ & 63.3 & $\mathrm{M}$ & \\
\hline${ }^{125} \mathrm{Sb}$ & 110 & $\mathrm{M}$ & \\
\hline${ }^{126} \mathrm{Sn}$ & 3.81 & $\mathrm{M}$ & \\
\hline${ }^{129} I$ & 0.336 & $\mathrm{M}$ & \\
\hline${ }^{134} \mathrm{Cs}$ & 12.7 & $\mathrm{E}$ & $\begin{array}{l}\text { Based on analyses of } 242-\mathrm{T} \\
\text { Evaporator salt cakes in other tanks. }\end{array}$ \\
\hline${ }^{137} \mathrm{Cs}$ & 315,000 & $M$ & \\
\hline${ }^{137 \mathrm{~m}} \mathrm{Ba}$ & 298,000 & $\mathrm{M}$ & \\
\hline${ }^{151} \mathrm{Sm}$ & 8,890 & $\mathrm{M}$ & \\
\hline${ }^{152} \mathrm{Eu}$ & 2.68 & $\mathrm{M}$ & \\
\hline${ }^{154} \mathrm{Eu}$ & 413 & $\dot{M}$ & \\
\hline${ }^{155} \mathrm{Eu}$ & 162 & $\mathrm{M}$ & \\
\hline${ }^{226} \mathrm{Ra}$ & $1.41 \mathrm{E}-04$ & $\mathrm{M}$ & \\
\hline${ }^{227} \mathrm{Ac}$ & $9.48 \mathrm{E}-04$ & $\mathrm{M}$ & \\
\hline${ }^{228} \mathrm{Ra}$ & 0.316 & $\mathrm{M}$ & \\
\hline${ }^{229} \mathrm{Th}$ & 0.00729 & $\mathrm{M}$ & \\
\hline${ }^{231} \mathrm{~Pa}$ & 0.00402 & $\mathrm{M}$ & \\
\hline${ }^{232} \mathrm{Th}$ & 0.0192 & $\mathrm{M}$ & \\
\hline${ }^{232} \mathrm{U}$ & 1.54 & $\mathrm{M}$ & \\
\hline
\end{tabular}


Revision 0

Table D4-2. Best-Basis Inventory Estimates for Radioactive Components in Tank 241-TX-117, Decayed to January 1, 1994 (Effective May 31, 1997). (2 sheets)

\begin{tabular}{|c|c|c|c|}
\hline Analyte & $\begin{array}{c}\text { Total inventory } \\
\text { (Ci) }\end{array}$ & $\begin{array}{c}\text { Basis } \\
(\mathrm{S}, \mathrm{M}, \text { or } \mathrm{E})^{1}\end{array}$ & Comment \\
\hline${ }^{233} \mathrm{U}$ & 5.92 & $\mathrm{M}$ & \\
\hline${ }^{234} \mathrm{U}$ & 5.12 & $\mathrm{M}$ & \\
\hline${ }^{235} \mathrm{U}$ & 0.223 & $\mathrm{M}$ & \\
\hline${ }^{236} \mathrm{U}$ & 0.0704 & $\mathrm{M}$ & \\
\hline${ }^{237} \mathrm{~Np}$ & 0.636 & $\mathrm{M}$ & \\
\hline${ }^{238} \mathrm{Pu}$ & 1.25 & $\mathrm{M}$ & \\
\hline${ }^{238} \mathrm{U}$ & 5.52 & $\mathrm{M}$ & \\
\hline${ }^{239} \mathrm{Pu}$ & 81.7 & $\mathrm{M}$ & \\
\hline${ }^{240} \mathrm{Pu}$ & 9.43 & $\mathrm{M}$ & \\
\hline${ }^{241} \mathrm{Am}$ & 39.7 & $\mathrm{M}$ & \\
\hline${ }^{241} \mathrm{Pu}$ & 74.0 & $\mathrm{M}$ & \\
\hline${ }^{242} \mathrm{Cm}$ & 0.0997 & $\mathrm{M}$ & \\
\hline${ }^{242} \mathrm{Pu}$ & $3.81 \mathrm{E}-04$ & $\mathrm{M}$ & \\
\hline${ }^{243} \mathrm{Am}$ & 0.00135 & $\mathrm{M}$ & \\
\hline${ }^{243} \mathrm{Cm}$ & 0.00909 & $\mathrm{M}$ & \\
\hline${ }^{244} \mathrm{Cm}$ & 0.0898 & $\mathrm{M}$ & \\
\hline${ }^{1} \mathrm{~S}$ & & & \\
\hline
\end{tabular}

${ }^{1} \mathrm{~S}=$ Sample-based

$M=$ Hanford Defined Waste model-based, Agnew et al. (1997a)

$\mathrm{E}=$ Engineering assessment-based. 
HNF-SD-WM-ER-711

Revision 0

This page intentionally left blank. 
HNF-SD-WM-ER-711

Revision 0

\section{D5.0 APPENDIX D REFERENCES}

Agnew, S. F., J. Boyer, R. A. Corbin, T. B. Duran, J. R. FitzPatrick, K. A. Jurgensen, T. P. Ortiz, and B. L. Young, 1996, Hanford Tank Chemical and Radionuclide Inventories: HDW Model Rev. 3, LA-UR-96-858, Los Alamos National Laboratory, Los Alamos, New Mexico.

Agnew, S. F., J. Boyer, R. A. Corbin, T. B. Duran, J. R. FitzPatrick, K. A. Jurgensen, T. P: Ortiz and B. L. Young, 1997a, Hanford Tank Chemical and Radionuclide Inventories: HDW Model Rev. 4, LA-UR-96-3860, Los Alamos National Laboratory, Los Alamos, New Mexico.

Agnew, S. F., R. A. Corbin, T. B. Duran, K. A. Jurgensen, T. P. Ortiz, and B. L. Young, 1997b, Waste Status and Transaction Record Summary (WSTRS Rev. 4), LA-UR-97-311, Rev. 0, Los Alamos National Laboratory, Los Alamos, New Mexico.

Allen, G. K., 1977, Salt Cake and Sludge Characterization Program 241-TX-116 Hot Test and Subsequent Cold Test Results, RHO-CD-3, Rockwell Hanford Operations, Richland, Washington.

Anderson, J. D., 1990, A History of the 200 Area Tank Farms, WHC-MR-0132, Westinghouse Hanford Company, Richland, Washington.

Baidwin, J. H., J. L. Stroup, L. C. Amato, and B. J. Morris, 1996, Tank Characterization Report for Single-Shell Tank 241-T-108, WHC-SD-WM-ER-554, Rev. OA, Westinghouse Hanford Company, Richland, Washington.

Brevick, C. H., J. L. Stroup, and J. W. Funk, 1997, Historical Tank Content Estimate for the Northwest Quadrant of the Hanford 200 West Area, HNF-SD-WM-ER-351, Rev. 1, Fluor Daniel Northwest Inc., Richland, Washington.

Brown, T. M., L. M. Sasaki, R. D. Cromar, N. G. Colton, J. L. Stroup, J. D. Franklin, and L. J. Fergestrom, 1996, Tank Characterization Report for Single-Shell Tank 241-T-109, WHC-SD-WM-ER-559, Rev. 0, Westinghouse Hanford Company, Richland Washington.

Brown, T. M., and J. Franklin, 1996, Tank Characterization Report for Single-Shell Tank 241-U-105, WHC-SD-WM-ER-617, Rev. 0, Westinghouse Hanford Company, Richland, Washington.

Buckingham, J. S., and W. P. Metz, 1974, Characterization of the Effects of Diatomaceous Earth Additions to Hanford Wastes, ARH-CD-222, Atlantic Richfield Hanford Company, Richland, Washington. 
Ecology, EPA, and DOE, 1994, Hanford Federal Facility Agreement and Consent Order, as amended, Washington State Department of Ecology, U.S. Environmental Protection Agency, and the U.S. Department of Energy, Olympia, Washington.

Hanlon, B. M., 1997, Waste Tank Summary Report for Month Ending February 28, 1997, HNF-EP-0182-107, Lockheed Martin Hanford Corporation, Richland, Washington.

Hill, J. G., G. S. Anderson, and B. C. Simpson, 1995, The Sort on Radioactive Waste Type Model: A Method to Sort Single-Shell Tanks into Characteristic Groups, PNL-9814, Rev. 2, Pacific Northwest Laboratory, Richland, Washington.

Hodgson, K. M. and M. D. LeClair, 1996, Work Plan for Defining A Standard Inventory Estimate for Wastes Stored in Hanford Site Underground Tanks, WHC-SD-WM-WP-311, Rev. 1, Lockheed Martin Hanford Corporation, Richland, Washington.

Horton, J. E., 1977, Physical and Chemical Characterization of Tank 116-TX, Letter to G. K. Allen, Atlantic Richfield Hanford Company, Richland, Washington.

Hu, T. A., L. C. Amato, R. T. Winward, and R. D. Cromar, 1997, Tank Characterization Report for Single-Shell Tank 241-U-102, HNF-SD-WM-ER-618, Rev. 0, Lockheed Martin Hanford Corporation, Richland, Washington.

Kummerer, M., 1995, Heat Removal Characteristics of Waste Storage Tanks, WHC-SD-WM-SARR-010, Rev. 1, Westinghouse Hanford Company, Richland, Washington.

Kupfer, M. J., A. L. Boldt, B. A. Higley, K. M. Hodgson, L. W. Shelton, B. C. Simpson, and R. A. Watrous (LMHC), S. L. Lambert, and D. E. Place (SESC), R. M. Orme (NHC), G. L. Borsheim (Borsheim Associates), N. G. Colton (PNNL), M. D. LeClair (SAIC), R. T. Winward (Meier Associates), and W. W. Schulz (W' ${ }^{2}$ S Corporation), 1997, Standard Inventories of Chemicals and Radionuclides in Hanford Site Tank Wastes, HNF-SD-WM-TI-740,-Rev. 0, Lockheed Martin Hanford Corporation, Richland, Washington.

Schulz, W. W., 1980, Removal of Radionuclides from Hanford Defense Waste Solutions, RHO-SA-51, Rockwell Hanford Operations, Richland, Washington.

Swaney, S. L., 1993, Waste Level Discrepancies Between Manual Level Readings and Current Waste Inventory for Single-Shell Tanks, (internal memo 7C242-93-038 to G. T. Frater, December 10), Westinghouse Hanford Company, Richland, Washington.

Watrous, R. A., and D. W. Wootan, 1997, Activity of Fuel Batches Processed Through Hanford Separations Plants, 1944 Through 1989, HNF-SD-WM-TI-794, Rev. 0, Lockheed Martin Hanford Corporation, Richland, Washington. 
HNF-SD-WM-ER-711

Revision 0

Weiss, R. L.and B. M. Mauss, 1987a, Data Transmittal Package for 241-TY-101 Waste Tank Characterization, SD-RE-TI-185, Rev. 0, Rockwell Hanford Operations, Richland Washington.

Weiss, R. L. and B. M. Mauss, 1987b, Data Transmittal Package for 241-TY-102 Waste Tank Characterization, SD-RE-TI-183, Rev. 0, Rockwell Hanford Operations, Richland Washington. 
HNF-SD-WM-ER-711

Revision 0

This page intentionally left blank. 